\title{
Characterization of changes in global gene expression in the brain of neuron-specific enolase/human Tau23 transgenic mice in response to overexpression of Tau protein
}

\author{
JONG-MIN WOO ${ }^{1,2}$, SO JUNG PARK ${ }^{1}$, HO IL KANG ${ }^{1}$, BYOUNG GUK KIM ${ }^{1}$, SUN BO SHIM ${ }^{1}$, SEUNG WAN JEE ${ }^{1}$, \\ SU HAE LEE ${ }^{1}$, JI SOON SIN ${ }^{1}$, CHANG JOON BAE ${ }^{1}$, MEE KYUNG JANG ${ }^{1}$, CHUNGHEE CHO ${ }^{2}$, \\ DAE YOUN HWANG ${ }^{3}$ and CHUEL KYU KIM ${ }^{1}$
}

\author{
${ }^{1}$ Division of Laboratory Animal Resources, National Institute of Food and Drug Safety Evaluation, Korea Food and Drug \\ Administration, Seoul 122-704; ${ }^{2}$ Department of Life Science, Gwangju Institute of Science and Technology, \\ Gwangju 500-712; ${ }^{3}$ Department of Biomaterials Science, College of Natural Resources and Life Science, \\ Pusan National University/PNU-LAR, Miryang 627-706, Republic of Korea
}

Received December 21, 2009; Accepted February 19, 2010

DOI: 10.3892/ijmm_00000390

\begin{abstract}
Tau is a neuronal phosphoprotein responsible for the formation of the neurofibrillary tangles in Alzheimer's disease. To characterize the changes in global gene expression in the brain of transgenic mice that overexpress human Tau23 protein in response to the increase of Tau 23 phosphorylation, total RNA extracted from the hippocampus of 12-month-old transgenic and wild-type mice was converted to cDNA, labeled with biotin and hybridized to oligonucleotide microarrays. The microarray results were confirmed by real-time RT-PCR and Western blotting method. It was determined that 43 genes were up-regulated and 8 genes were down-regulated by Tau23 in transgenic mice compared to controls, based on the arbitrary difference in the 2-fold change. Among the up-regulated transcripts, those encoding for transporter and oxidoreductase were dramatically over-represented, followed by those related to regulatory molecule, cytoskeletal protein, signaling molecule, and extracellular matrix protein. Genes encoding for transcription factor, regulatory molecule, miscellaneous function, and chaperone were significantly reduced in the downregulated group. The major genes in the up-regulated categories
\end{abstract}

Correspondence to: Professor Dae Youn Hwang, Department of Biomaterials Science, College of Natural Resources and Life Science, Pusan National University, 50 Cheonghak-ri, Samnangjin-eup, Miryang-si, Gyeongsangnam-do 627-706, Republic of Korea E-mail: dyhwang@pusan.ac.kr

Dr Chuel Kyu Kim, Division of Laboratory Animal Resources, National Institute of Food and Drug Safety Evaluation, Korea FDA, 194 Tongilro, Eunpyung-ku, Seoul 122-704, Republic of Korea E-mail: ok kim@kfda.go.kr

Key words: Alzheimer's disease, microarray, transgenic mice, Tau23 protein included Ecrg4, Folr1, Defb11, Aqp1 and Soctdc1. The major genes in the down-regulated categories were Ncor1, Gpm6a, and Hspd1. These results indicate that the microarray analysis identifies several gene functional groups and individual genes that respond to a sustained increase in Tau23 phosphorylation levels in the brain of transgenic mice. In addition, the results suggest the microarray test is a useful tool for increased understanding of the role of Tau 23 protein in regulating neurodegenerative disorders.

\section{Introduction}

Alzheimer's disease (AD) is a brain disorder that leads to severe problems in memory, thought, and behavior. Patients with AD have difficulties in career, lifestyle, and social life. Currently, 12 million people are affected with $\mathrm{AD}$ and the number is predicted to triple by 2050 world-wide $(1,2)$. The common pathogenic figures of $\mathrm{AD}$ are senile plaques, neurofibrillary tangles (NFTs), dystrophic neurites, extensive neuronal loss, and gliosis (3). Currently, the most credible hypothesis regarding senile plaques is that they form by reversible aggregation of $A \beta$ in clusters $(4,5)$. $A \beta$ peptides are generated by sequential cleavages of APP by $\beta$ - and $\gamma$-secretase $(6,7)$. The increased $A B$ production and deposition in the brain may trigger neuronal dysfunction and death in AD. Furthermore, NFTs, a different pathological hallmark of $\mathrm{AD}$, are composed of paired helical filament (PHF)-Tau (8). Tau is a neuronal phosphoprotein that has tubulin-polymerizing activities in vitro and establishes short cross-bridges between axonal microtubules $(9,10)$. Also, this protein is regulated by various protein kinases and phosphatases (11). Among the kinases, cyclindependent kinase-5 (cdk5) and glycogen synthase-kinase 3ß (GSK3ß) are predominant Tau kinases in the brain (12-15).

Phosphorylated Tau has a reduced affinity for microtubules and a reduced ability to promote microtubule assembly (16-19). Hyperphosphorylated Tau protein becomes aggregated into toxic insoluble filaments and leads to cell death. In the adult brain, Tau is primarily located in axons, but hyperphos- 
phorylated Tau is found in cell bodies and dendrites in the AD brain. Results from in vitro studies suggest that the degree of dementia correlates with the severity of Tau-based NFTs (11). Such observations suggest that the phosphorylation of Tau plays a significant role in regulating the dynamics of microtubule assembly/disassembly in neurons (9). Several transgenic (Tg) mice were developed by inducing the overexpression of the human Tau (hTau) gene $(20,21)$. In particular, neuronspecific enolase (NSE)/hTau23 Tg mice were generated by microinjection of the fusion gene into the male pronucleus of fertilized embryos in order to study the mechanism of AD. This fusion gene was constructed by the hTau 23 gene cloned under the control NSE promoter (22). In these Tg mice, the increase of Tau phosphorylation and PHFs induced by the overexpression of Tau at the age of 12-months was observed. For this reason, these $\mathrm{Tg}$ mice serve as a useful model to study the relationship between genes and the mechanisms of AD. In addition, this model is available for testing new drug candidates. However, there is no study in which genes have been regulated by Tau 23 phosphorylation using the modifications developed in these $\mathrm{Tg}$ mice.

In this study, we characterized the changes in global gene expression in the brain of $\mathrm{Tg}$ overexpressing hTau 23 gene in response to an increased phosphorylation level of Tau 23 protein. A total of 51 genes were identified using microarray analysis in 12-month-old $\mathrm{Tg}$ mice compared to wild-type mice. Also, these genes involved various genes related with cell physiology such as transporter, defense/immunity protein, oxidoreductase and transcription factor. Furthermore, some of the genes with up- and down-regulation were validated by quantitative RT-PCR and Western blotting. From the analysis of our data, we identified several known genes that had not been linked to $\mathrm{AD}$ in the past. This study may help in the search for genes associated to AD and will help with understanding the prevention, clinical diagnosis, and treatment of neurodegeneration.

\section{Materials and methods}

Animals. We used Tg mice that overexpressed the hTau23 gene, which were developed in our laboratory by microinjecting the fusion gene into the male pronucleus of fertilized embryos. Embryos were obtained by crossing C57BL/6 (female) mice with DBA2 (male) mice (22). All pedigrees were hemizygous for the implanted transgene. In order to determine the gene expression profiles, we used 12-month-old NSE/hTau23 mice $(n=6)$ and wild-type mice $(n=6)$ for purification of total RNA from brain. All mice were handled in an accredited Korea FDA animal facility in accordance with AAALAC International Animal Care policy (Accredited Unite-Korea Food and Drug Administration, Unit Number-000996). All experiments and protocols were approved by the Institutional Animal Care and Use Committee. The mice were housed in cages under a strict light cycle (lights on at 06:00 h and off at 18:00 h). All mice were given a standard irradiated chow diet (Purina Mills Inc., Korea) ad libitum, and were maintained in a specific pathogen-free state.

Western blotting. The proteins that were prepared from the hippocampuses of the $\mathrm{Tg}$ and wild-type mice were separated by electrophoresis in a $12 \%$ SDS-PAGE gel for $2 \mathrm{~h}$ at $40 \mathrm{Vol}$. Each membrane was incubated separately with the primary, anti-Tau (sc-5587, rabbit polyclonal, 1:2,500; Santa Cruz Biotechnology) at $37^{\circ} \mathrm{C}$ for $2 \mathrm{~h}$ and anti-phospho-Tau $\left(\mathrm{Thr}^{231}\right.$, rabbit polyclonal, 1:500, Sigma), anti-Aqp1 (sc-25287, mouse monoclonal, 1:500, Santa Cruz Biotechnology), and anti-Folr 1 (sc-28997, rabbit polyclonal, 1:500, Santa Cruz Biotechnology) at $4^{\circ} \mathrm{C}$ overnight. The membranes were washed with washing buffer $\left(137 \mathrm{mM} \mathrm{NaCl}, 2.7 \mathrm{mM} \mathrm{KCl}, 10 \mathrm{mM} \mathrm{Na} \mathrm{HPO}_{4}, 2 \mathrm{mM}\right.$ $\mathrm{KH}_{2} \mathrm{PO}_{4}$, and $0.05 \%$ Tween-20) and incubated with horseradish peroxidase-conjugated goat anti-rabbit $\operatorname{IgG}(1: 5,000)$ or antimouse $\operatorname{IgG}(1: 5,000)$ at room temperature for $2 \mathrm{~h}$. The membrane blots were developed using a Chemiluminescence Reagent Plus kit (ECL Plus; Amersham Biosciences).

RNA isolation. The hippocampuses from 12-month-old Tg and wild-type mice were used as the source of isolating total RNA through the use of Trizol (Invitrogen Life Technologies, Carlsbad, USA), then purified using RNeasy columns (Qiagen, Valencia, USA). Both were performed according to the manufacturer's protocol. First, $30 \mathrm{mg}$ of frozen hippocampuses were lysed though the use of lysis buffer and homogenized using a rotor-stator homogenizer. Next, 70\% ethanol was added to the homogenate, and samples were then applied to an RNeasy minispin column for total RNA to bind to the resin in the column. Total RNA was eluted in the RNasefree-water. After processing with DNase digestion, clean-up procedures, RNA samples were quantified, aliquoted, and stored at $-80^{\circ} \mathrm{C}$ until use. For quality control, RNA purity and integrity were evaluated by denaturing gel electrophoresis, OD 260/280 ratio, and analyzed on Agilent 2100 Bioanalyzer (Agilent Technologies, Palo Alto, USA).

Labeling and purification. Total RNA was amplified and purified using the Ambion Illumina RNA amplification kit (Ambion, Austin, USA). To produce biotinylated cRNA according to the manufacturer's instructions, $550 \mathrm{ng}$ of total RNA was reverse-transcribed to cDNA using a T7 oligo(dT) primer. A second-strand of cDNA was synthesized, transcribed in vitro, and labeled with biotin-NTP. After purification, the cRNA was quantified using the ND-1000 Spectrophotometer (NanoDrop, Wilmington, USA).

Hybridization and data export. We hybridized $750 \mathrm{ng}$ of labeled cRNA samples to each mouse- 6 expression bead array for $16-18 \mathrm{~h}$ at $58^{\circ} \mathrm{C}$, according to the manufacturer's instructions (Illumina, Inc., San Diego, USA). The array signal was detected using Amersham fluorolink streptavidin-Cy3 (GE Healthcare Bio-Sciences, Little Chalfont, UK) following the bead array manual. Arrays were scanned using an Illumina Bead Array Reader Confocal Scanner (BeadStation 500GXDW; Illumina, Inc.) according to the manufacturer's instructions. Array data export processing and analysis was performed using Illumina BeadStudio.

Raw data preparation. The quality of hybridization and overall chip performance were monitored by visual inspection of both internal quality control checks and the raw scanned data. We extracted the raw data using the software provided by the manufacturer (BeadStudio v.3.1). Array data were filtered by 
use of P-value set at $<0.05$ (similar to signal to noise) in at least $50 \%$ samples. We applied a filtering criterion for data analysis; higher signal value was required to obtain a detection of $\mathrm{P}<0.05$. Selected gene signal value was transformed by logarithm and normalized by Quantile method to remove systemic bias. Data reliability was measured by scatter plot method. Correlation coefficients (Rs) of normalized samples were revealed as ranging from 0.95 to 0.99 , which indicates that systematic variation of non-biological origin was removed. The comparative analysis between transgenic and nontransgenic mouse samples were carried out using the t-test (Ifoldl $>$ or $<2$ ) and the adjusted Benjamini-Hochberg FDR (false discovery rate) P-value $(<0.05)$ (23). We performed volcano plots and hierarchical cluster analysis using complete linkage and Euclidean distance as measures of similarity. Timedependent profiling was achieved by k-means cluster analysis (k, 9, Euclidean distance, complete linkage). All data analysis and visualization of differentially expressed genes were conducted using ArrayAssist ${ }^{\circledR}$ (Stratagene, La Jolla, USA). Biological pathway and ontology-based analysis were performed by using the Protein Analysis Through Evolutionary Relationships (PANTHER) database (http://www. pantherdb. org).

Quantitative real-time RT-PCR. cDNA was produced using the Superscript ${ }^{\mathrm{TM}}$ ॥ RT-PCR System (Invitrogen, Karlsruhe, Germany) according to the manufacturer's recommendations for oligo (dT) 20-primed cDNA-synthesis. cDNA synthesis was performed on $500 \mathrm{ng}$ of RNA, at $42^{\circ} \mathrm{C}$. Finally, cDNA samples were diluted 2-fold in water before QPCR analysis. PCR was performed in an ABI PRISM 7900HT Sequence Detection System (Applied Biosystems, CA, USA), and performed in 384-well microtiter plates using a final volume of $10 \mu$ l. Optimum reaction conditions were obtained with $5 \mu 1$ of Universal Master Mix (Applied Biosystems), which contained dNUTPs, $\mathrm{MgCl}_{2}$, reaction buffer, Ampli Taq Gold, $90 \mathrm{nM}$ of primer(s), and $250 \mathrm{nM}$ fluorescence-labeled TaqMan probe. Finally, $2 \mu 1$ template cDNA was added to the reaction mixture. The 6 primer/TaqMan probe combinations were designed from sequences from the NCBI public database. Amplifications were performed starting with a 10 min template denaturation step at $95^{\circ} \mathrm{C}$, followed by 40 cycles at $95^{\circ} \mathrm{C}$ for $15 \mathrm{sec}$ and $60^{\circ} \mathrm{C}$ for $1 \mathrm{~min}$. All samples were amplified in triplicate, data were analyzed with sequence detector software (Applied Biosystems). After normalization with GAPDH, we analyzed the expression level of genes in experimental groups using the comparative method $(\Delta \mathrm{Ct})$. Then, these data that analyzed the above results were also compared with data obtained from microarray in order to verify the variation between the two methods.

Statistical analysis. In the microarray analyses, significance between wild-type mice and $\mathrm{Tg}$ mice were performed using a t-test. Also, one-way ANOVA test (SPSS for Windows, Release 10.10, Standard Version, Chicago, USA) were performed to determine the variance and significance between wild-type mice and $\mathrm{Tg}$ mice on the level of specific protein expression. All values are represented as the mean \pm standard deviation (SD), with the mean difference between $\mathrm{Tg}$ mice considered statistically significant at $\mathrm{P}<0.05$.
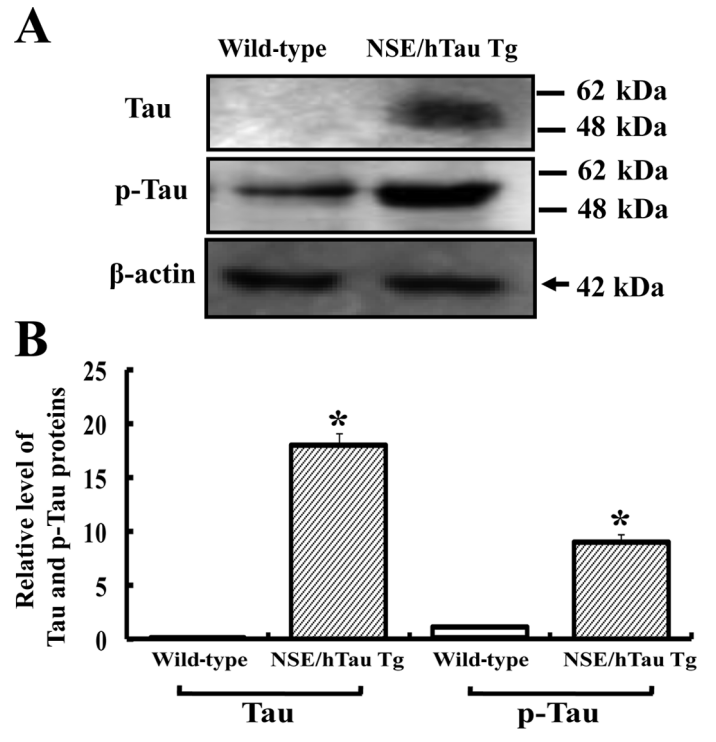

Figure 1. Expression level of total and phosphate-form Tau23 in wild-type and NSE/hTau23 Tg mice. The hippocampal tissues of 12-month-old wild-type mice and $\mathrm{Tg}$ mice were pooled, respectively, prior to protein analysis. Tau overexpression and its phosphorylation were examined by Western blotting using anti-Tau and phospho-Tau $\left(\mathrm{pThr}^{231}\right)$ antibodies. Data represent the mean \pm SD from three replicates. ${ }^{*} \mathrm{P}<0.05$, significant level compared with the $\mathrm{Tg}$ mice.

\section{Results}

Change of Tau expression and phosphorylation in NSE/hTau23 $\mathrm{Tg}$ mice. It was reported that the expression level of Tau protein was significantly higher in the NSE/hTau23 Tg than in wild-type mice (22). Therefore, first we examined whether hTau23 gene was successfully expressed and phosphorylated in the Tg mice used in this study. Expression level of hTau23 protein and p-hTau23 were detected in the samples of hippocampuses from 12-month-old mice. As shown in Fig. 1, the Tg mice showed a higher level of hTau proteins than wild-type mice. Furthermore, the level of p-Tau protein was significantly increased in the hippocampuses of Tg mice compared to that of wild-type mice, although this antibody had a cross-activity for mice protein. These results suggested that the hippocampus region of $\mathrm{Tg}$ mice showed a higher level of total hTau and $\mathrm{p}$-hTau protein than wild-type mice, respectively.

Image of the gene expression profile on cDNA microarray. A microarray analysis plot of the microarray gene expression data is shown in Fig. 2. The location of average gene expression values along the first diagonal showed a non-systematic bias between the wild-type and Tg groups. A higher variance was observed at the higher compared to lower expression levels. A fairly considerable number of genes were also expressed at elevated or at reduced levels in a $\mathrm{Tg}$ mouse hippocampus compared to the wild-type mice hippocampus. However, expression levels of most genes showed no difference between the $\mathrm{Tg}$ and wild-type hippocampus.

Filtering and selection for differentially-expressed genes. To identify the genetic profile of particular genes involved in response to phosphorylation of Tau 23 protein, total RNA of each hippocampal tissue was successfully hybridized to the 


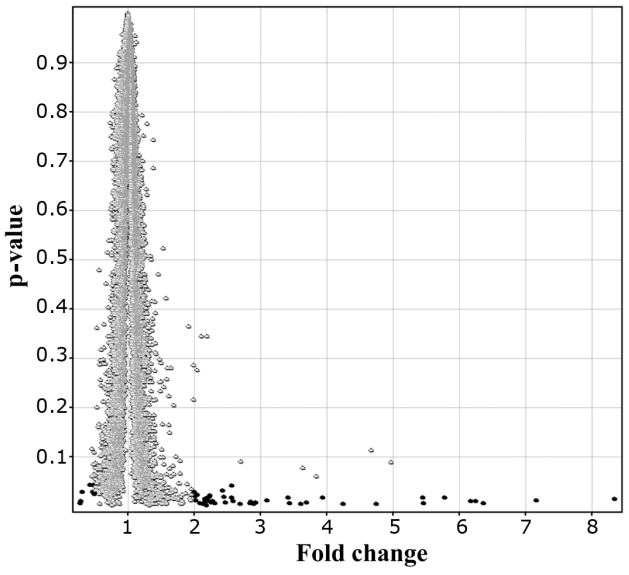

Figure 2. Volcano plots. Each point represents the average expression value for the same gene from the wild-type and $\mathrm{Tg}$ mice. The vertical axis represents the $\mathrm{P}$-value and the horizontal axis represents the fold change. Black points represent the 51 significant genes that display biological importance and statistical significance.

Table I. Selection of differentially expressed genes.

\begin{tabular}{lc}
\hline Categories & Number of transcripts \\
\hline Total & 24,886 \\
Filtered gene & 12,072 \\
lfold $\geq 2$ & 51 \\
\hline
\end{tabular}

Among a total of 24,886 individual mouse transcripts, 51 transcripts were selected as differentially expressed on a statistically significant basis in comparison to the control mice because the expression levels showed a fold change of $\geq 2$ with a $\mathrm{P}<0.05$.

Mouse- 6 expression Beadchip microarrays containing 24,886 probes. A total of 12,072 genes were detected as differentially expressed genes in Tg mice compared to wildtype mice. Of these genes, further analysis was performed based on the arbitrary difference in the 2-fold change with a t-test, $\mathrm{P}<0.05$. It was revealed that 51 genes were up-regulated and down-regulated in the Tg mice compared to the wild-type mice (Table I). These results suggested that the novel genes were successfully identified by the microarray analysis under the condition of Tau23 overexpression.

Ontology categories of Tau23-regulated gene expression. To analyze the ontology classification of the Tau23-regulated gene expression in the hippocampus of $\mathrm{Tg}$ mice, the gene lists were categorized into functional clustering according to the Gene Ontology classification using the PANTHER/X ontology on-line software; the results are presented in Table II. PANTHER/X ontology identified 15 GO categories showing significantly elevated expressions in the list of up-regulated transcripts (Table IIA). As presented in Table II, the largest number of transcripts turned out to be associated with transporter proteins and oxidoreductase proteins. From the list of down-regulated transcripts, PANTHER/X ontology identified 5 markedly overexpressed GO categories (Table IIB). In this group, the transcripts of those genes located on the transcription factor were especially highly expressed, followed by those
Table II. Gene ontology categories. Gene ontology was classified by using PANTHER database categories.

A, Up-regulated genes involved 14 categories and 1 unclassified group at the level of significance.

\begin{tabular}{llc}
\hline P-value & \multicolumn{1}{c}{ GO category } & $\begin{array}{c}\text { Number of } \\
\text { transcripts }\end{array}$ \\
\hline 0.0119 & Transporter & 5 \\
0.0123 & Oxidoreductase & 5 \\
0.0092 & Regulatory molecule & 3 \\
0.0210 & Cytoskeletal protein & 3 \\
0.0097 & Signaling molecule & 2 \\
0.0078 & Extracellular matrix protein & 2 \\
0.0081 & Hydrolase & 2 \\
0.0043 & Cell junction protein & 2 \\
0.0196 & Ion channel & 2 \\
0.0050 & Defense/immunity protein & 2 \\
0.0118 & Transcription factor & 2 \\
0.0057 & Receptor & 1 \\
0.0074 & Miscellaneous function & 1 \\
0.0080 & Transferase & 1 \\
0.0160 & Molecular function unclassified & 10 \\
\hline
\end{tabular}

B, Down-regulated genes involved 4 categories and 1 unclassified group at the level of significance.

\begin{tabular}{llc}
\hline P-value & \multicolumn{1}{c}{ GO category } & $\begin{array}{c}\text { Number of } \\
\text { transcripts }\end{array}$ \\
\hline 0.0191 & Transcription factor & 2 \\
0.0428 & Regulatory molecule & 1 \\
0.0295 & Miscellaneous function & 1 \\
0.0426 & Chaperone & 1 \\
0.0195 & Molecular function unclassified & 3 \\
\hline
\end{tabular}

involved in regulatory molecules, miscellaneous function, and chaperone. These results suggest that Tau 23 protein regulates the expression of genes related to transporter, oxidoreductase activity, and transcription factor for gene expression in the hippocampuses of $\mathrm{Tg}$ mice.

Genes with the highest expression level of up- and downregulation. In order to characterize the genes showing the highest overexpression, those with at least a 2-fold increase were selected from the 43 up-regulated genes and 8 downregulated genes. As shown in Table III, the highest increase was in transcripts Ecrg4 (8.35-fold) identified as a cancerrelated gene, followed by Folr1, Defb11, Aqp1, Sostdc1, and Prlr. The various transporters and immunity proteins were elevated by the regulation of Tau 23 protein in the hippocampuses of $\mathrm{Tg}$ mice. In addition, 8 genes with the highest fold change were significantly decreased (Table IV). Of these genes, RIKEN cDNA 9630050M13 gene which has unidentified functions, was the most most dramatically decreased, followed by Ncor1, Gpm6a, Hspd1, Rab7 and Rnfl4. These results indicate that Tau 23 protein is closely 
Table III. Genes (43) with the highest folding increase among those up-regulated in the hippocampus of NSE/hTau23 Tg mice.

\begin{tabular}{|c|c|c|c|c|c|}
\hline Gene symbol & Gene name & Accession No. & $\begin{array}{l}\text { Fold of } \\
\text { change }\end{array}$ & P-value & GO category \\
\hline Ecrg4 & $\begin{array}{l}\text { esophageal cancer } \\
\text { related gene } 4\end{array}$ & NM_024283 & 8.35 & 0.0140 & \\
\hline Folr1 & folate receptor 1 & NM_008034 & 7.18 & 0.0110 & Transporter \\
\hline Defb11 & defensin $ß 11$ & NM_139221 & 6.37 & 0.0057 & Defense/immunity protein \\
\hline 1600023A02Rik & & NM_026323 & 6.24 & 0.0098 & regulatory molecule \\
\hline Aqp1 & aquaporin 1 & NM_007472 & 6.17 & 0.0106 & Transporter \\
\hline Sostdc 1 & $\begin{array}{l}\text { sclerostin domain } \\
\text { containing } 1\end{array}$ & NM_025312 & 5.78 & 0.0172 & \\
\hline Prlr & prolactin receptor & NM_011169 & 5.46 & 0.0057 & Receptor \\
\hline Clic6 & $\begin{array}{l}\text { chloride intracellular } \\
\text { channel } 6\end{array}$ & NM_172469 & 5.46 & 0.0178 & Ion channel \\
\hline Cldn2 & claudin 2 & NM_016675 & 4.75 & 0.0043 & Cell junction protein \\
\hline Cox $8 b$ & $\begin{array}{l}\text { cytochrome c oxidase, } \\
\text { subunit VIIIb }\end{array}$ & NM_007751 & 4.23 & 0.0050 & Oxidoreductase \\
\hline Calml4 & calmodulin-like 4 & NM_138304 & 3.95 & 0.0177 & \\
\hline Rdh5 & retinol dehydrogenase 5 & NM_134006 & 3.68 & 0.0069 & Oxidoreductase \\
\hline Lbp & $\begin{array}{l}\text { lipopolysaccharide } \\
\text { binding protein }\end{array}$ & NM_008489 & 3.60 & 0.0043 & $\begin{array}{l}\text { Defense/immunity } \\
\text { protein }\end{array}$ \\
\hline $\mathrm{Kl}$ & klotho & NM_013823 & 3.43 & 0.0063 & Hydrolase \\
\hline Otx2 & $\begin{array}{l}\text { orthodenticle homolog } 2 \\
\text { (Drosophila) }\end{array}$ & NM_144841 & 3.41 & 0.0173 & Transcription factor \\
\hline Col8a2 & procollagen, type VIII, $\alpha 2$ & NM_199473 & 3.09 & 0.0113 & $\begin{array}{l}\text { Extracellular matrix } \\
\text { protein }\end{array}$ \\
\hline 1600023A02Rik & $\begin{array}{l}\text { RIKEN cDNA 1600023A02 gene } \\
\text { (1600023A02Rik), mRNA }\end{array}$ & NM_026323 & 2.93 & 0.0069 & regulatory molecule \\
\hline Cldn 1 & $\begin{array}{l}\text { claudin } 1 \\
\text { RIKEN cDNA } \\
2810046 \mathrm{M} 22 \text { gene }\end{array}$ & $\begin{array}{l}\text { NM_016674 } \\
\text { NM_026621 }\end{array}$ & $\begin{array}{l}2.89 \\
2.85\end{array}$ & $\begin{array}{l}0.0043 \\
0.0085\end{array}$ & Cell junction protein \\
\hline 1110059M19Rik & $\begin{array}{l}\text { RIKEN cDNA } \\
1110059 \mathrm{M} 19 \text { gene }\end{array}$ & XM_135842 & 2.84 & 0.0066 & \\
\hline Col8a1 & procollagen, type VIII, $\alpha 1$ & NM_007739 & 2.70 & 0.0043 & $\begin{array}{l}\text { Extracellular matrix } \\
\text { protein }\end{array}$ \\
\hline Sulf1 & sulfatase 1 & NM_172294 & 2.59 & 0.0099 & Hydrolase \\
\hline Mia1 & & NM_019394 & 2.56 & 0.0177 & \\
\hline Dncl2b & $\begin{array}{l}\text { dynein, cytoplasmic, } \\
\text { light chain } 2 \mathrm{~B}\end{array}$ & NM_029297 & 2.56 & 0.0416 & Cytoskeletal protein \\
\hline Igfbp2 & $\begin{array}{l}\text { insulin-like growth factor } \\
\text { binding protein } 2\end{array}$ & NM_008342 & 2.46 & 0.0074 & Miscellaneous function \\
\hline Tuba6 & tubulin, alpha 6 & XM_147357 & 2.45 & 0.0193 & Cytoskeletal protein \\
\hline AI427515 & expressed sequence AI427515 & NM_173016 & 2.42 & 0.0321 & Oxidoreductase \\
\hline Msx 1 & homeo box, msh-like 1 & NM_010835 & 2.31 & 0.0063 & Transcription factor \\
\hline Cdkn1c & $\begin{array}{l}\text { cyclin-dependent kinase } \\
\text { inhibitor } 1 \mathrm{C}(\mathrm{P} 57)\end{array}$ & NM_009876 & 2.27 & 0.0109 & regulatory molecule \\
\hline Sema3b & $\begin{array}{l}\text { sema domain, immunoglobulin } \\
\text { domain (Ig), short basic domain, } \\
\text { secreted, (semaphorin) 3B }\end{array}$ & NM_009153 & 2.26 & 0.0080 & Signaling molecule \\
\hline Trpm3 & $\begin{array}{l}\text { transient receptor } \\
\text { potential cation channel, } \\
\text { subfamily } \mathrm{M} \text {, member } 3\end{array}$ & NM_177341 & 2.23 & 0.0213 & Ion channel \\
\hline Slc39a4 & $\begin{array}{l}\text { solute carrier family } 39 \\
\text { (zinc transporter), member } 4\end{array}$ & NM_028064 & 2.22 & 0.0193 & Transporter \\
\hline 2410146L05Rik & RIKEN cDNA 2410146L05 gene & NM_026480 & 2.22 & 0.0099 & \\
\hline Tekt1 & tektin 1 & NM_011569 & 2.18 & 0.0022 & Cytoskeletal protein \\
\hline Tsga2 & testis specific gene A2 & NM_025290 & 2.18 & 0.0163 & \\
\hline 2310016C16Rik & RIKEN cDNA 2310016C16 gene & NM_027127 & 2.17 & 0.0117 & Oxidoreductase \\
\hline Hemk1 & & NM_133984 & 2.16 & 0.0080 & Transferase \\
\hline
\end{tabular}


Table III. Continued.

\begin{tabular}{|c|c|c|c|c|c|}
\hline Gene symbol & Gene name & Accession No. & $\begin{array}{l}\text { Fold of } \\
\text { change }\end{array}$ & P-value & GO category \\
\hline Slc4a2 & $\begin{array}{l}\text { solute carrier family } 4 \\
\text { (anion exchanger), member } 2\end{array}$ & NM_009207 & 2.16 & 0.0142 & Transporter \\
\hline Aqp1 & aquaporin 1 & NM_007472 & 2.12 & 0.0043 & Transporter \\
\hline 2310016C16Rik & RIKEN cDNA $2310016 C 16$ gene & NM_027127 & 2.08 & 0.0057 & Oxidoreductase \\
\hline 1700009P17Rik & RIKEN cDNA 1700009P17 gene & NM_029301 & 2.04 & 0.0237 & \\
\hline Igf2 & insulin-like growth factor 2 & NM_010514 & 2.03 & 0.0114 & Signaling molecule \\
\hline ВС013481 & cDNA sequence BC013481 & NM_178446 & 2.01 & 0.0287 & \\
\hline
\end{tabular}

Table IV. Genes (8) with the highest folding decrease among those down-regulated from the hippocampus of NSE/hTau23 Tg mice.

\begin{tabular}{llllll}
\hline Gene symbol & \multicolumn{1}{c}{ Gene name } & Accession No. & $\begin{array}{c}\text { Fold of } \\
\text { change }\end{array}$ & P-value & GO category \\
\hline 9630050M13Rik & RIKEN cDNA 9630050M13 gene & XM_194000 & -3.72 & 0.0057 & Transcription factor \\
Ncor1 & nuclear receptor co-repressor 1 & NM_011308 & -3.50 & 0.0099 & Miscellaneous function \\
Gpm6a & glycoprotein m6a & NM_153581 & -3.27 & 0.0295 & Chaperone \\
Hspd1 & heat shock protein 1 (chaperonin) & NM_010477 & -2.38 & 0.0426 & Regulatory molecule \\
C030032C09Rik & RIKEN cDNA C030032C09 gene & NM_181398 & -2.14 & 0.0283 & \\
Rab7 & RAB7, member RAS oncogene family & NM_009005 & -2.08 & 0.0428 & Transcription factor \\
5830457O10Rik & RIKEN cDNA 5830457O10 gene & NM_145412 & -2.05 & 0.0246 & -2.03 \\
Rnf14 & ring finger protein 14 & NM_020012 & 0.0283 &
\end{tabular}

Table V. Comparison of expression ratios of selected genes from the hippocampus of NSE/hTAu23 Tg and wild-type Tg mice, as determined by real-time PCR and microarray analysis.

\begin{tabular}{llcc}
\hline $\begin{array}{l}\text { Gene } \\
\text { symbol }\end{array}$ & Accession No. & $\begin{array}{c}\text { Microarray } \\
\text { fold change }\end{array}$ & $\begin{array}{c}\text { Q-PCR } \\
\text { fold change }\end{array}$ \\
\hline Lbp & NM_008489 & 3.60 & 4.81 \\
Folr1 & NM_008034 & 7.18 & 12.27 \\
Aqp1 & NM_007472 & 6.17 & 13.94 \\
Ncor1 & NM_011308 & -3.50 & -1.03 \\
Gpm6a & NM_153581 & -3.27 & -1.01 \\
\hline
\end{tabular}

involved in the regulation of genes that function as transporters, defense proteins, regulatory molecules, and transcription factors under the condition of a Tau23 abnormal phosphorylation level.

Validation of microarray data. To validate the reliability of the results obtained from the microarray analysis, we performed real-time RT-PCR. We selected candidate genes according to the following criteria: i) genes showing a high magnitude in fold change, ii) genes annotated with function, and iii) genes linked to neuronal diseases. Accordingly, five up-regulated genes (Lbp, Folr1, and Aqp1) and two down-regulated genes (Ncor1 and Gpm6a) were selected and analyzed. When comparing the results of the microarray data and that of the

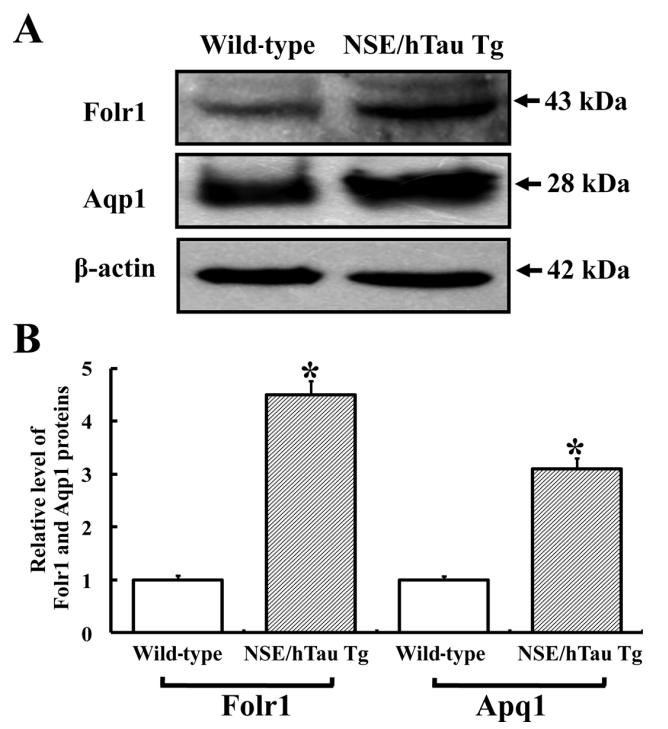

Figure 3. Change of Folr 1 and Aqp 1 protein level in wild-type and NSE/hTau23 Tg mice. The hippocampal tissues of 12-month-old wild-type mice and $\mathrm{Tg}$ mice were pooled, respectively, prior to protein analysis. Folr 1 and Aqp 1 expression were examined by Western blotting using anti-Folr 1 and Aqp1 antibodies. The data represents the mean \pm SD from three replicates. ${ }^{*} \mathrm{P}<0.05$, significant level compared with $\mathrm{Tg}$ mice.

real-time RT-PCR, the results of PCR analysis were further increased in the 3 up-regulated genes, although pattern increase was very similar in the two methods. However, the expression 
of down-regulated genes was decreased to a lesser extent in the PCR analysis compared to the microarray data (Table V). Furthermore, to investigate correlation between transcriptional and protein levels, we analyzed protein expression levels by Western blotting. Folr1 and Aqp1 were chosen, based on the greatest changes (12- and 14-fold increases, respectively) among the candidates. As shown in Fig. 3, we observed the apparent up-regulation of Folr1 and Aqp1 expression in protein level. Therefore, this result corroborates the data from our microarray analysis.

\section{Discussion}

In normal human nerve cells, Tau is a normally soluble protein essential for maintaining the shape and structural integrity. Also, this protein plays an important role in transportation between cellular compartments by association with neuronal axons. Under pathological conditions, Tau is excessively phosphorylated, which destabilizes microtubules. Several Tau animal models have been developed by introducing the wildtype/mutant Tau gene or altering the Tau-transgene promoter. Although none have completely reproduced the disease process, animal models are widely accepted as an excellent tool for studying the disease mechanism and screening novel drugs.

Here we found several interesting genes related to AD mechanism and pathogenesis. The Folr gene encodes folate receptor $\alpha(\mathrm{FR} \alpha)$, which has the ability to bind folate (24). RT-PCR analysis, using RNA extracted from the fibroblast of $\mathrm{AD}$, showed that, from cultured fibroblasts of $\mathrm{AD}, \mathrm{FR} \alpha \mathrm{mRNA}$ was significantly higher in $\mathrm{AD}$ fibroblasts than in controls, which suggests that higher folate binding in AD fibroblast is due to an enhanced expression of $\mathrm{FR} \alpha$ (25). Its up-regulation is very similar to that determined by this microarray study. Therefore, this gene may serve as a biomarker for AD diagnosis. Aquaporins (AQPs) are a family of transmembrane proteins that act as water selective channels (26). In the brain, AQP1 is found in the apical pole of the choroidal plexus of epithelial cells and ependimocytes $(27,28)$. A possible relationship between the AQP increase and spongiform degeneration has been suggested by AQP1 increase in Creuzfelt-Jakob disease (CJD) patients and in Bovine spongiform encephalopathy (BSE) found in infected mice (29). Interestingly, Western blotting studies have shown a significant increase in the level of aqpl in the frontal cortex in sporadic $\mathrm{AD}$ cases (30). In our study, aqpl was found, for the first time, to be expressed highly in the hippocampus in the model mice for AD. It may be expected that the tau overexpression alters AQP1 level, which disrupts water and ion homeostasis in the cell, and may induce the neurodegenerative mechanism of AD. Claudin is a multigene family member protein that is involved in the formation of tight junctions in various tissues $(31,32)$. A highly sensitive nested RT-PCR analysis showed that from claudin-2 to -8 mRNA was present in the rat hippocampus and in frontal cortex tissues (33). Although individual claudin may be responsible for the establishment or maintenance of tissue architecture, specific physiological roles for the particular claudins are still unknown. The blood-brain barrier (BBB) has been considered to be intact during neurodegenerative diseases such as AD and Parkinson's disease (PD), however, recent evidence argues otherwise. Endothelial cells exposed to $20 \mu \mathrm{M}$ of $A \beta_{1-42}$ altered the expression pattern of tight junction proteins, occludin, claudin-1, and ZO-2 $(34,35)$. In the present study, our results reveal a 4.75 -fold increase of claudin-2 mRNA level and 2.89-fold increase of claudin-1 mRNA in the $\mathrm{Tg}$ mice overexpressing Tau protein. These results support the hypothesis that tight junction components in BBB dysfunction induce neurodegenerative disease progression. It was also recently suggested that $\mathrm{BBB}$ development is controlled by Wnt/B-catenin signaling (36-38). Liebner et al suggested that Wnt/B-catenin signaling drives claudin expression, based on results from experiments using mice expressing both loss and gain of function mutant of $\beta$-catenin. Previously, the hTau23 Tg mice exhibited high levels of GSK3ß phosphorylation with advanced age, resulting in increases in the phosphorylations of tau and B-catenin. Thus, it is possible that claudin genes showing altered expression levels in the transgenic mice are regulated by phosphorylation of these proteins directly or indirectly.

The nuclear receptor corepressor $(\mathrm{N}-\mathrm{CoR} 1)$ is a co-regulator required for mediation of active repression by specific nuclear receptors and several additional classes of transcription factors $(39,40)$. In situ hybridization and dual-label immunofluorescence studies have shown that $\mathrm{N}-\mathrm{CoR} 1$ is expressed ubiquitously in the brain tissue of young adult male rats (41). Our results reveal that overexpression of human wild-type Tau reduced $N$-CoRl transcript, but this finding appears to be in conflict with previous microarray data using SH-SY5Y neuroblastoma cells expressing P301L mutant Tau. Hoerndli et al (42) have suggested that N-CoR1 was modestly upregulated (1.58-fold) when $A \beta_{42}$ treatment was combined with P301L tau expression. Despite the fact that N-CoR1 was identified years ago as prominently expressed in the brain, little is known about its biological involvement in brain disorders or in AD. Glycoprotein M6a (Gpm6a, M6a) is a neuronal membrane protein $(43,44)$. Alfonso et al $(45)$ have shown that M6a plays an important role in neurite/filopodium outgrowth and synapse formation. They found the M6a gene was downregulated in the hippocampus of socially and physically stressed animals. In the hippocampus of AD patients, M6a expression has been shown to be down-regulated (46). Here, we have provided compelling evidence that the $M 6 a$ gene is decreased in the transgenic mouse, therefore, these data support the notion that chronic stress by Tau pathology is related with M6a protein dysfunction and AD progression.

There is little overlap between the gene profiles reported in this study and those from previously-reported microarraybased studies in AD brain tissues. This could be due to diversity and complexity in $\mathrm{AD}$ pathogenesis in humans, compared to our system which overexpresses a single gene. In addition, subtle methodological differences, such as statistical methods in normalization and filtering, and microarray platforms, might be responsible for disconcordance between the mouse and human microarray data. Since AD pathogenesis is still incompletely understood, our results should be valuable in interpreting data from future studies on $\mathrm{AD}$ pathogenesis in human as well as animal models.

In conclusion, we identified and validated differential gene expression due to the overexpression of human Tau protein. The hippocampal regions from 12-month-old Tg and wild-type mice were used. The hippocampus is selected because this tissue is 
closely linked to the declining cognitive performance in AD patients. The present study identified 51 differentially expressed genes associated with Tau pathology in the humanized AD model mice. This was confirmed by performing quantitative reverse PCR and Western blotting. Thus, these genes may contribute to the development of new therapeutic targets.

\section{Acknowledgements}

We thank Mr. Henry Kwon for his guidance on microarray and real-time RT-PCR experiments. We also thank Sunmi Choi, B.S. and Ms. Jermlan Song for directing the Animal care and use at the Division of Laboratory Animal Resources. This work was supported by a grant for Scientific Research of the Korea FDA.

\section{References}

1. Hebert LE, Scherr PA, Bienias JL, Bennett DA and Evans DA: Alzheimer disease in the US population: prevalence estimates using the 2000 census. Arch Neurol 60: 1119-1122, 2003.

2. Citron M: Strategies for disease modification in Alzheimer's disease. Nat Rev Neurosci 5: 677-685, 2004.

3. Wang DS, Dickson DW and Malter JS: B-Amyloid degradation and Alzheimer's Disease. J Biomed Biotech 2006: 58406, 2006.

4. Urbanc B, Cruz L, Buldyrev SV, Havlin S, Irizarry MC, Stanley HE and Hyman BT: Dynamics of plaque formation in Alzheimer's disease. J Biophys 76: 1330-1334, 1999.

5. Cruz L, Urbanc B, Buldyrev SV, Christie R, Gómez-Isla T, Havlin S, McNamara M, Stanley HE and Hyman BT: Aggregation and disaggregation of senile plaques in Alzheimer disease. Proc Natl Acad Sci USA 94: 7612-7616, 1997.

6. Mattson MP: Pathways towards and away from Alzheimer's disease. Nature 430: 631-639, 2000.

7. Evin G and Weidemann A: Biogenesis and metabolism of Alzheimer's disease A beta amyloid peptides. Peptide 23: 1285-1297, 2002.

8. Brion JP, Couck AM, Passareiro E and Flament-Durand J: Neurofibrillary tangles of Alzheimer's disease: an immunohistochemical study. J Submicrosc Cytol 17: 89-96, 1985.

9. Utton MA, Vandecandelaere A, Wagner U, Reynolds $\mathrm{CH}$, Gibb GM, Miller CC, Bayley PM and Anderton BH: Phosphorylation of tau by glycogen synthase kinase 3beta affects the ability of tau to promote microtubule self-assembly. Biochem J 323: 741-747, 1997

10. Friedhoff P, von Bergen M, Mandelkow EM and Mandelkow E: Structure of tau protein and assembly into paired helical filaments. Biochim Biophys Acta 1502: 122-132, 2000.

11. Billingsley ML and Kincaid RL: Regulated phosphorylation and dephosphorylation of tau protein: effects on microtubule interaction, intracellular trafficking and neurodegeneration. Biochem J 323: 577-591, 1997.

12. Ahlijanian MK, Barrezueta NX, Williams RD, Jakowski A, Kowsz KP, McCarthy S, Coskran T, Carlo A, Seymour PA, Burkhardt JE, Nelson RB and McNeish JD: Hyperphosphorylated tau and neurofilament and cytoskeletal disruptions in mice overexpressing human p25, an activator of cdk5. Proc Natl Acad Sci USA 97: 2910-2915, 2000.

13. Leroy K, Yilmaz Z and Brion JP: Increased level of active GSK-3beta in Alzheimer's disease and accumulation in argyrophilic grains and in neurones at different stages of neurofibrillary degeneration. Neuropathol Appl Neurobiol 33: 43-55, 2007.

14. Schindowski K, Belarbi K, Bretteville A, Ando K and Buée L: Neurogenesis and cell cycle-reactivated neuronal death during pathogenic tau aggregation. Genes Brain Behav 7 (suppl 1): 92-100, 2008.

15. Wagner U, Utton M, Gallo JM and Miller CC: Cellular phosphorylation of tau by GSK-3 beta influences tau binding to microtubules and microtubule organisation. J Cell Sci 109: 1537-1543, 1996.

16. Biernat J, Gustke N, Drewes G, Mandelkow EM and Mandelkow E: Phosphorylation of Ser262 strongly reduces binding of tau to microtubules: Distinction between PHF-like immunoreactivity and microtubule binding. Neuron 11: 153-163, 1993.
17. Lu Q and Wood JG: Functional studies of Alzheimer's disease tau protein. J Neurosci 13: 508-515, 1993.

18. Trinczek B, Biernat J, Baumann K, Mandelkow EM and Mandelkow E: Domains of tau protein, differential phosphorylation, and dynamic instability of microtubules. Mol Biol Cell 6: 1887-1902, 1995.

19. Lindwall G and Cole RD: Phosphorylation affects the ability of tau to promote microtubule assembly. J Biol Chem 259: 5301-5305, 1984.

20. Spires TL and Hyman BT: Transgenic models of Alzheimer's Disease: Learning from animals. NeuroRx 2: 423-437, 2005.

21. Hutton M, Lewis J, Dickson D, Yen SH and McGowan E: Analysis of tauopathies with transgenic mice. Trends Mol Med 7: 467-470, 2001

22. Shim SB, Lim HJ, Chae KR, Kim CK, Hwang DY, Jee SW, Lee SH, Sin JS, Leem YH, Lee SH, Cho JS, Lee HH, Choi SY and Kim YK: Tau overexpression in transgenic mice induces glycogen synthase kinase 3beta and beta-catenin phosphorylation. Neuroscience 146: 730-740, 2007

23. Benjamini Y and Hochberg Y: Controlling the false discovery rate: a practical and powerful approach to multiple testing. J Roy Statist Soc Ser B 57: 289-300, 1995.

24. Elnakat $\mathrm{H}$ and Ratnam M: Distribution, functionality and gene regulation of folate receptor isoforms: implications in targeted therapy. Adv Drug Deliv Rev 56: 1067-1084, 2004.

25. Cazzaniga E, Bulbarelli A, Lonati E, Re F, Galimberti G, Gatti E, Pitto M, Ferrarese C and Masserini M: Enhanced folate binding of cultured fibroblasts from Alzheimer's disease patients. Neurosci Lett 436: 317-320, 2008.

26. Costa C, Tortosa R, Rodríguez A, Ferrer I, Torres JM, Bassols A and Pumarola M: Aquaporin 1 and aquaporin 4 overexpression in bovine spongiform encephalopathy in a transgenic murine model and in cattle field cases. Brain Res 1175: 96-106, 2007.

27. Nielsen S, Smith BL, Christensen EI and Agre P: Distribution of the aquaporin chip in secretory and resorptive epithelia and capillary endothelia. Proc Natl Acad Sci USA 90: 7275-7727, 1993.

28. Nagy G, Szekeres G, Kvell K, Berki T and Németh P: Development and characterisation of a monoclonal antibody family against aquaporin 1 (Aqp1) and aquaporin 4 (Aqp4). Pathol Oncol Res 8: 115-124, 2002.

29. Rodriguez A, Pérez-Gracia E, Espinosa JC, Pumarola M, Torres JM and Ferrer I: Increased expression of water channel aquaporin 1 and aquaporin 4 in Creutzfeldt-Jakob disease and in bovine spongiform encephalopathy-infected bovine-PrP transgenic mice. Acta Neuropathol 112: 573-585, 2006.

30. Pérez E, Barrachina M, Rodríguez A, Torrejón-Escribano B, Boada M, Hernández I, Sánchez M and Ferrer I: Aquaporin expression in the cerebral cortex is increased at early stages of Alzheimer disease. Brain Res 1128: 164-174, 2007.

31. Morita K, Furuse M, Fujimoto K and Tsukita S: Claudin multigene family encoding four-transmembrane domain protein components of tight junction strands. Proc Natl Acad Sci USA 96: 511-516, 1999.

32. Morita K, Sasaki H, Furuse M and Tsukita S: Endothelial claudin: claudin-5/TMVCF constitutes tight junction strands in endothelial cells. J Cell Biol 147: 185-194, 1999.

33. Lamas M, González-Mariscal L and Gutiérrez R: Presence of claudins mRNA in the brain. Selective modulation of expression by kindling epilepsy. Brain Res Mol Brain Res 104: 250-254, 2002.

34. Marco S and Skaper SD: Amyloid beta-peptide1-42 alters tight junction protein distribution and expression in brain microvessel endothelial cells. Neurosci Lett 401: 219-224, 2006.

35. Desai BS, Monahan AJ, Carvey PM and Hendey B: Blood-brain barrier pathology in Alzheimer's and Parkinson's disease: implications for drug therapy. Cell Transplant 16: 285-299, 2007.

36. Liebner SM, Corada M, Bangsow T, Babbage J, Taddei A, Czupalla CJ, Reis M, Felici A, Wolburg H, Fruttiger M, Taketo MM, von Melchner H, Plate KH, Gerhardt H and Dejana E: Wnt/B-catenin signaling controls development of the blood-brain barrier. J Cell Biol 183: 409-417, 2008.

37. Polakis P: Formation of the blood-brain barrier: Wnt signaling seals the deal. J Cell Biol 183: 371-373, 2008.

38. Zlokovic BV: The blood-brain barrier in health and chronic neurodegenerative disorders. Neuron 57: 178-201, 2008

39. Van der Laan S, Lachize SB, Vreugdenhil E, de Kloet ER and Meijer OC: Nuclear receptor coregulators differentially modulate induction and glucocorticoid receptor-mediated repression of the corticotropin-releasing hormone gene. Endocrinology 149: 725-732, 2008. 
40. Jepsen K, Hermanson O, Onami TM, Gleiberman AS, Lunyak V, McEvilly RJ, Kurokawa R, Kumar V, Liu F, Seto E, Hedrick SM, Mandel G, Glass CK, Rose DW and Rosenfeld MG: Combinatorial roles of the nuclear receptor corepressor in transcription and development. Cell 102: 753-763, 2000.

41. Van der Laan S, Lachize SB, Schouten TG, Vreugdenhil E, de Kloet ER and Meijer OC: Neuroanatomical distribution and colocalisation of nuclear receptor corepressor $(\mathrm{N}-\mathrm{CoR})$ and silencing mediator of retinoid and thyroid receptors (SMRT) in rat brain. Brain Res 1059: 113-121, 2005.

42. Hoerndli FJ, Pelech S, Papassotiropoulos A and Götz J: Abeta treatment and P301L tau expression in an Alzheimer's disease tissue culture model act synergistically to promote aberrant cell cycle re-entry. Eur J Neurosci 26: 60-72, 2007.

43. Lagenaur C, Kunemund V, Fischer G, Fushiki S and Schachner M Monoclonal M6 antibody interferes with neurite extension of cultured neurons. J Neurobiol 23: 71-88, 1992.
44. Olinsky S, Loop BT, DeKosky A, Ripepi B, Weng W, Cummins J, Wenger SL, Yan Y, Lagenaur C and Narayanan V: Chromosomal mapping of the human M6 genes. Genomics 33: 532-536, 1996.

45. Alfonso J, Fernández ME, Cooper B, Flugge G and Frasch AC: The stress-regulated protein M6a is a key modulator for neurite outgrowth and filopodium/spine formation. Proc Natl Acad Sci USA 102: 17196-17201, 2005.

46. Xu PT, Li YJ, Qin XJ, Scherzer CR, Xu H, Schmechel DE, Hulette CM, Ervin J, Gullans SR, Haines J, Pericak-Vance MA and Gilbert JR: Differences in apolipoprotein E3/3 and E4/4 allele-specific gene expression in hippocampus in Alzheimer disease. Neurobiol Dis 21: 256-275, 2006. 